Phytochemistry, 1970, Vol. 9, pp. 1811 to 1815. Pergamon Press. Printed in England.

\title{
BIOSYNTHESIS OF PHENOLIC TETRAHYDROISOQUINOLINE ALKALOIDS OF PEYOTE ${ }^{1}$
}

\author{
K. L. Khanna, M. Takido, H. Rosenberg and A. G. Paul \\ College of Pharmacy, The University of Michigan, Ann Arbor, Mi. 48104, U.S.A.
}

(Received 5 November 1969)

\begin{abstract}
Data are presented supporting a proposed pathway of biosynthesis of the phenolic tetrahydroisoquinoline alkaloids of peyote from dopamine. It is suggested that meta- $O$-methylation of dopamine, hydroxylation in the 5-position, para-O-methylation and finally cyclizations yield anhalamine, anhalidine, anhalonidine and pellotine.
\end{abstract}

\section{INTRODUCTION}

THOUGH in vivo investigations of the biosynthesis of mescaline in peyote (Lophophora williamsii (Lem.) Coult.) are relatively complete, ${ }^{1-10}$ reports on the biosynthesis of the isoquinoline alkaloids are less so. Battersby et $a .^{11}$ have reported the incorporation of tyrosine into pellotine, lophophorine and anhalonidine. Further, they demonstrated that dopamine was incorporated into pellotine and that the methyl group of methionine served as a precursor of the $O$-methyl groups but not of the $\mathrm{C}-1$ and $\mathrm{C}-9$ positions of this alkaloid. While $1-{ }^{14} \mathrm{C}$-labeled acetate was incorporated into pellotine, the activity was found to be evenly distributed between the C-1 and C-9 positions suggesting that it is not incorporated directly.

Subsequently, these authors have reported ${ }^{12}$ that though 4-hydroxy-3-methoxyphenethylamine serves as a precursor of pellotine 5-hydroxy-3,4-dimethoxyphenethylamine does not. When ${ }^{14} \mathrm{C}$-labeled pellotine was introduced into plants, 4.9 per cent of the radioactivity was recovered as anhalonidine. However when ${ }^{14} \mathrm{C}$-labeled anhalonidine was introduced, only 1.5 per cent of the radioactivity was recovered as pellotine.

Leete ${ }^{2}$ has also shown that tyrosine acts as a precursor of anhalonidine. In addition, Leete and Braunstein ${ }^{13}$ have reported that $3-{ }^{14} \mathrm{C}$-labeled pyruvate was incorporated into the C-1 and C-9 unit of anhalonidine. The percentage of incorporation ( 0.06 per cent) and the distribution of activity (28 per cent in C-1; 72 per cent in C-9) suggests that pyruvate is not incorporated directly. Lundström and Agurell ${ }^{9}$ have reported that the methyl group of

${ }^{1}$ J. Chem. Soc. D. 838 (1969).

${ }^{2}$ E. LeETE, J. Am. Chem. Soc. 88,4218 (1966).

3 J. L. McLaughlin and A. G. PAUL, Lloydia 30, 91 (1967).

4 H. Rosenberg, J. L. Mclaughlin and A. G. Paul, Lloydia 30, 100 (1967).

${ }^{5}$ K. L. Khanna, H. Rosenberg and A. G. Paul, J. Chem. Soc. D. 315 (1969).

6 A. G. Paul, K. L. Khanna, H. Rosenderg and M. Takido, J. Chem. Soc. D. 838 (1969).

${ }^{7}$ H. Rosenberg, K. L. Khanna, M. Takido and A. G. Paul, Lloydia 32, 334 (1969).

8 S. AGURELL, J. LUNDSTRÖM and F. SANDBERG, Tetrahedron Letters 2433 (1967).

9 J. LUNDSTRÖM and S. AGURELL, Tetrahedron Letters 4437 (1968).

$10 \mathrm{~J}$. LUNDSTRÖM and S. AGURELL, Tetrahedron Letters 3371 (1969).

11 A. R. BATTERSBY, R. Binks and R. HuxtaBle, Tetrahedron Letters 563 (1967).

12 A. R. BATTERSBY, R. BinKS and R. HUXTABLE, Tetrahedron Letters 6111 (1968).

${ }^{13}$ E. LeETE and J. D. BRAUNSTEIN, Tetrahedron Letters 451 (1969). 
methionine was incorporated into the $O$-methyl groups of anhalonidine and anhalamine and, in addition, into the $\mathrm{C}-1$ unit of anhalamine. Their data further demonstrate that tyrosine ( 0.34 per cent), dopamine ( 1.73 per cent) and 3,4,5-trihydroxyphenethylamine ( 1.73 per cent) serve as efficient precursors of anhalamine. In studies of a related alkaloid, lophocerine, O'Donovan and Horan ${ }^{14}$ have shown that tyrosine serves as a precursor of the $C_{6}-C_{2}-N$ portion and that leucine and mevalonate serve as precursors of the remaining $C_{5}$ unit.

The incorporation of several phenethylamines into mescaline suggested to us that a similar pathway of biosynthesis of the phenolic tetrahydroisoquinoline alkaloids might be operable in peyote.

\section{RESULTS AND DISCUSSION}

Table 1 lists the percentages of radioactivity of the $8-{ }^{14} \mathrm{C}$-labeled phenethylamines injected into peyote plants recovered as anhalamine, anhalonidine and pellotine.

The alkaloids, isolated as the $\mathrm{HCl}$ salts, were recrystallized to constant specific activity. Picrate and chloroaurate derivatives were prepared and assayed in order to determine constancy of specific activities. Where derivatives differed markedly in specific activity from the $\mathrm{HCl}$ salt or when the percentage of incorporation was low $(<0.40$ per cent), the alkaloids were not treated further. All others were converted to the corresponding $O, N$-dimethyl methiodide and the hydroxide oxidized in alkaline $\mathrm{KMnO}_{4}$ to 3,4,5-trimethoxyphthalic anhydride. The isolated and recrystallized anhydride was assayed for radioactivity and, in each instance, was shown to contain $<1$ per cent of the original radioactivity. Kuhn-Roth oxidation of the quaternary hydroxides yielded acetic acid which was converted to p-bromophenacyl acetate. Assay of this derivative demonstrated that $<1$ per cent of the radioactivity resided in the C-1 and C-9 positions of anhalonidine and pellotine in each instance. By deduction, $>98$ per cent of the radioactivity resided in the predicted C-3 position of each alkaloid. Within the framework of the assumptions previously reported, ${ }^{4}$ these data support the hypothesis that the pathway of biosynthesis of the phenolic tetrahydroisoquinoline alkaloids of peyote follows the scheme shown in Fig. 1.

While the percentages of incorporation of the proposed precursors into pellotine are low, the percentages incorporated into anhalonidine and anhalamine are high and consistent with the proposed scheme. This apparent contradiction may be explained by comparing the data of Battersby et al..$^{12}$ on the interconversion of anhalonidine and pellotine, which suggests that the reaction favors the formation of anhalonidine. The moderately high percentage of incorporation of 3-hydroxy-4-methoxyphenethylamine into the alkaloids, approximately onethird to one-half that of 4-hydroxy-3-methoxyphenethylamine, suggests that the former may be isomerized to the latter. This has been shown to occur in animal systems. ${ }^{15}$

In a previous investigation, ${ }^{1}$ we reported that $3,4,5$-trihydroxyphenethylamine was poorly incorporated into anhalonidine ( 0.12 per cent) and pellotine $(0.06$ per cent). When the experiment was repeated a moderately high percentage of incorporation of this precursor into these alkaloids was observed (Table 1) and the percentage of incorporation into anhalamine was essentially identical with that reported by Lundström and Agurell. ${ }^{9}$ One possible explanation for the discrepancy between these data is that carrier alkaloids were added prior to isolation in the present investigation and were not added in the previous one. Losses during isolation and purification could account for the differences in calculated percentages

14 D. G. O'Donovan and H. Horan, J. Chem. Soc. C. 2791 (1968).

15 F. A. Kueht, M. Hickens, R. E. Ormond, M. A. P. Meisinger, P. H. Gale, V. J. Cirillo and N. G. Brink, Nature 203, 154 (1964). 
<smiles>NCCc1ccc(O)c(O)c1</smiles><smiles>COc1cc(CCN)ccc1O</smiles>

4-hydroxy-3-methoxyphenethylamine<smiles>COc1cc(CCN)cc(O)c1O</smiles>

4,5-dihydroxy-3-methoxyphenethylamine<smiles>COc1cc(CCN)cc(O)c1OC</smiles>

3,4-dimethoxy-5-hydroxyphenethylamine<smiles>COc1cc2c(c(O)c1OC)CNCC2</smiles>

anhalamine<smiles>C1CC1</smiles><smiles>COc1cc2c(c(O)c1OC)CN(C)CC2</smiles>

$\theta={ }^{14} \mathrm{C}$<smiles>COc1cc2c(c(O)c1OC)C(C)NCC2</smiles>
anhalonidine<smiles>[Te]=[Te]</smiles><smiles>COc1cc2c(c(O)c1OC)C(C)N(C)CC2</smiles>

pellotine

Fig. 1. Proposed pathway of biosynthesis of phenolic tetrahydroisoQuinoline peyote ALKALOIDS. 
of incorporation. The presently reported data lend support to the suggestion ${ }^{12}$ that cyclizations of this compound to 3,4,5-trihydroxytetrahydroisoquinolines may precede $O$-methylations in the biosynthesis of these alkaloids. That this alternative pathway may also be operable in peyote is under investigation.

TABle 1. Per CENT INJeCted Radioactivity ReCOVERED AS PHENOLIC TETRAHYDROISOQUINOLINE ALKALOIDS

\begin{tabular}{|c|c|c|c|}
\hline \multirow{2}{*}{$\begin{array}{l}\text { Test compound: } \\
\text { Substituted phenethylamine }\end{array}$} & \multicolumn{3}{|c|}{$\%$ Radioactivity recovered as } \\
\hline & Anhalonidine & Pellotine & Anhalamine \\
\hline 4-hydroxy-3-methoxy & $2 \cdot 20$ & 0.37 & 1.72 \\
\hline 3-hydroxy-4-methoxy & 0.74 & 0.17 & 0.90 \\
\hline 3,4-dimethoxy & 0.002 & 0.002 & - \\
\hline 3,4,5-trihydroxy & 0.99 & 0.64 & $1 \cdot 69$ \\
\hline 4,5-dihydroxy-3-methoxy & $3 \cdot 23$ & 0.77 & 3.90 \\
\hline 3,4-dimethoxy-5-hydroxy & $6 \cdot 24$ & $0 \cdot 26$ & 5.96 \\
\hline 3,5-dimethoxy-4-hydroxy & $0 \cdot 16$ & 0.03 & 0.05 \\
\hline
\end{tabular}

The data support the suggestion that the pathway of biosynthesis of the phenolic tetrahydroisoquinoline alkaloids of peyote is similar to that of mescaline ${ }^{7}$ up to the point of $O$-methylation of 4,5-dihydroxy-3-methoxyphenethylamine. para $O$-methylation of this compound rather than meta $O$-methylation leads to 3,4-dimethoxy-5-hydroxyphenethylamine. Cyclizations of this latter compound give rise to the phenolic tetrahydroisoquinoline alkaloids of peyote.

\section{EXPERIMENTAL}

\section{Preparation and Administration of Test Compounds}

The $8{ }^{14} \mathrm{C}$-labeled phenethylamines employed as test compounds are listed in Table 2 . With the exception of 3,4-dimethoxyphenethylamine, which was obtained commercially, the radioactive compounds were synthesized by reported procedures which are noted. M.ps, mixed m.ps and i.r. spectra were used as criteria for identity. In addition, each compound was chromatographed on silica gel (Eastman Chromatogram Sheet 6060) using $\mathrm{MeOH}-\mathrm{EtOAc}-\mathrm{NH}_{4} \mathrm{OH}(5: 5: 0 \cdot 1)$. Examination using an Atomic Associates Radiochromatogram scanner indicated that each compound was homogeneous.

Plants of $L$. williamsii were maintained in a controlled environment lab under conditions previously reported. ${ }^{3}$ The radioactive test compounds were introduced by the method previously described. ${ }^{3}$ Specific activities and amounts injected are shown in Table 2.

\section{Assay for Radioactivity}

All compounds were prepared and assayed using a Beckman LS-200 Liquid Scintillation System by the procedures described previously. ${ }^{16}$

\section{Isolation and Purification of Alkaloids}

The total alkaloids were isolated and separated into phenolic and nonphenolic fractions by the methods reported previously. ${ }^{17}$ The phenolic extract was dissolved in $\mathrm{CHCl}_{3}$, extracted with $10 \%$ citric acid solution $(2 \times 10 \mathrm{ml})$ and the $\mathrm{CHCl}_{3}$ solution discarded. Carrier pellotine $\mathrm{HCl}$ and anhalonidine $\mathrm{HCl}(100-125 \mathrm{mg})$ were added to the aqueous solution and the $\mathrm{pH}$ adjusted to 4.0 with conc. $\mathrm{NH}_{4} \mathrm{OH}$. This solution was extracted with $\mathrm{CHCl}_{3}(2 \times 10 \mathrm{ml})$ and the $\mathrm{CHCl}_{3}$ solution discarded. The aqueous solution was adjusted to $\mathrm{pH} 5.0$ and extracted with $\mathrm{CHCl}_{3}$ in a liquid-liquid extractor for $24 \mathrm{hr}$. The $\mathrm{CHCl}_{3}$ extract was evaporated to dryness, dissolved in $5 \mathrm{ml}$ methanol and $200 \mathrm{ml}$ ether added. The solution was filtered to remove the precipitate and the filtrate was concentrated to approximately $5 \mathrm{ml}$. Dry $\mathbf{H C l}$ gas was passed through this solution, a small quantity of ether added and the pellotine $\mathrm{HCl}$ which crystallized was recovered and recrystallized from methanol:ether to constant specific activity.

16 A. G. PAUL, H. Rosenberg and K. L. KhanNa, Lloydia 32, 36 (1969).

17 J. L. MCLAUGhlin and A. G. PAUL, Lloydia 29, 315 (1966). 
TABLE 2. 8- ${ }^{14} \mathrm{C}$-LABELED PHENETHYLAMINE SYNTHESIZED AND TESTED

\begin{tabular}{lccc}
\hline Substituted phenethylamine & Procedure & $\begin{array}{c}\text { Specific } \\
\text { activity } \\
(\mathrm{mc} / \mathrm{mM})\end{array}$ & $\begin{array}{c}\text { Amount } \\
\text { injected } \\
(\mu \mathrm{c})\end{array}$ \\
\hline 4-hydroxy-3-methoxy & $\mathrm{a}$ & 1.93 & 129 \\
3-hydroxy-4-methoxy & $\mathrm{a}$ & 1.29 & 123 \\
3,4-dimethoxy & $\mathrm{b}$ & 17.6 & 200 \\
3,4,5-trihydroxy & $\mathrm{c}$ & 1.91 & 108 \\
4,5-dihydroxy-3-methoxy & $\mathrm{d}$ & 0.75 & 55 \\
3,4-dimethoxy-5-hydroxy & $\mathrm{e}$ & 2.38 & 135 \\
3,5-dimethoxy-4-hydroxy & $\mathrm{f}$ & 1.68 & 137 \\
\hline
\end{tabular}

a. A. Ramiriz and A. Burger, J. Am. Chem. Soc. 72, 2781 (1950);

- Purchased from I.C.N. Corp., City of Industry, Calif;;

- G. HAHN and F. RUMPF, Chem. Ber 71B, 2141 (1938);

a F. Benington, R. D. Morin and L. C. Clarke, JR., J. Org. Chem. 20, 1292 (1955);

- J. Ratcliffe and P. Smith, Chem. Ind. London 955 (1959);

' F. Benington, R. D. Morin and L. C. Clarke, JR., J. Am. Chem. Soc. 76, 5555 (1954).

The aqueous solution was then adjusted to $\mathrm{pH} 6.0$ and extracted with $\mathrm{CHCl}_{3}$ for $24 \mathrm{hr}$ using a liquidliquid extractor. The $\mathrm{CHCl}_{3}$ solution was evaporated to dryness and the extract was dissolved in $5 \mathrm{ml}$ methanol. Dry $\mathrm{HCl}$ gas was passed through this solution, a small volume of ether added and the anhalonidine $\mathrm{HCl}$ which crystallized was recovered and recrystallized from methanol:ether to constant specific activity.

The aqueous solution was finally adjusted to $\mathrm{pH} \mathrm{9.0} \mathrm{and} \mathrm{extracted} \mathrm{with} \mathrm{CHCl}_{3}$ for $24 \mathrm{hr}$ in a liquid-liquid extractor. The $\mathrm{CHCl}_{3}$ cxtract was concentrated to dryness, the extract dissolved in a small quantity of methanol and the mother liquor obtained after crystallization of anhalonidine (pH 6.0 extraction) was added. In order to separate the anhalamine from hordenine and traces of anhalonidine, this solution was subjected to preparative TLC. The solution was spotted on a plate ( $8 \mathrm{in} . \times 8 \mathrm{in}$.) of silica gel $\mathrm{H}(2 \mathrm{~mm}$ thick) and this developed with $\mathrm{CHCl}_{3}-\mathrm{Me}_{2} \mathrm{CO}-\mathrm{HNEt}_{2}$ (5:4:1). The band representing anhalamine was removed from the plate and eluted with $\mathrm{CHCl}_{3}-\mathrm{MeOH}(9: 1)$. The solution was concentrated to dryness, the residue was dissolved in $5 \mathrm{ml}$ methanol and carrier anhalamine $\mathrm{HCl}(80-100 \mathrm{mg})$ was added. Dry $\mathrm{HCl}$ gas was passed through this solution, a small quantity of ether added and the anhalamine $\mathrm{HCl}$ which crystallized was recovered and recrystallized from $\mathrm{MeOH}-\mathrm{Et}_{2} \mathrm{O}$ to constant specific activity.

Picrate and chloroaurate derivatives of each alkaloid were prepared by standard procedures.

\section{Degradation of the Alkaloids}

Each alkaloid was converted to the corresponding $O, N$-dimethylmethiodide by refluxing first with $\mathrm{NaOEt}$, then with MeI and finally with $\mathrm{Na}_{2} \mathrm{CO}_{3}$ and additional MeI. ${ }^{2}$ The methiodide was isolated, crystallized from EtOH-EtOAc- $\mathrm{Et}_{2} \mathrm{O}$ and converted to the corresponding hydroxide with freshly precipitated $\mathrm{AgOH}$. The hydroxide was oxidized in alkaline $\mathrm{KMnO}_{4}(1 \%)$ to 3,4,5-trimethoxyphthalic anhydride. ${ }^{18}$ The m.p. of the anhydride, recrystallized from benzene: $n$-hexane and of its 2,4-dinitrophenylhydrazone were essentially identical to those reported in the literature. ${ }^{19}$

The $O, N$-dimethylmethiodides of anhalonidine and pellotine were converted to the hydroxide by passing a solution in $50 \%$ methanol through a column of Amberlite IRA $401\left(\mathrm{OH}^{-}\right)$ion exchange resin. The eluant was concentrated to dryness and the residue was subjected to Kuhn-Roth oxidation following the method of Gros and Leete. ${ }^{20}$ The acetic acid formed was recovered by water distillation and, employing the method of Hall, ${ }^{21}$ converted to $p$-bromophenacyl acetate. The acetate was purified by column chromatography on silicic acid using $\mathrm{CHCl}_{3}$ as the eluant and recrystallized from petroleum ether (b.p. $30^{\circ}-60^{\circ}$ ). The m.p. of $p$-bromophenacyl acetate isolated in each instance was essentially identical with that reported. ${ }^{21}$

Acknowledgement-The authors are deeply indebted to Dr. A. Brossi, Hoffmann-La Roche Inc., Nutley, N. J. for his generosity in supplying samples of alkaloids.

${ }^{18}$ E. Späth and F. BeCKE, Chem. Ber. 67, 2100 (1934).

19 E. MakKawa and S. NanYa, Bull. Chem. Soc. Japan 32, 1311 (1969).

${ }^{20}$ E. G. Gros and E. Leete, J. Am. Chem. Soc. 87, 1375 (1965).

${ }^{21}$ E. S. HALL, Synthesis and Biosynthesis of Indole Alkaloids, Doctoral Dissertation, University of British Columbia (1960). 